\title{
Thermal behavior of the products of 2-chloro-2-propen-1-ol oligomerization
}

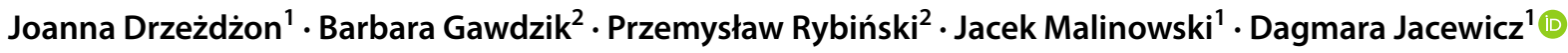

Received: 23 September 2019 / Accepted: 4 August 2020 / Published online: 17 August 2020

(c) The Author(s) 2020

\begin{abstract}
The thermal stability of the oligomers obtained by using 2-chloro-2-propen-1-ol as the monomer has been studied. The oligomers were synthesized using chromium(III) and oxovanadium(IV) complexes as the catalysts after activation by modified methylaluminoxane (MMAO-12). The complexes used as the catalysts were polycarboxylate complex compounds of oxovanadium(IV) and chromium(III). The studies have been conducted by two methods: thermal gravimetry and differential scanning calorimetry. The obtained results allow to determine the glass transition temperatures and thermal stability of the oligomers depending on the central catalyst cation $\mathrm{Cr}^{3+}$ and $\mathrm{V}^{4+}$.
\end{abstract}

Keywords Catalyst · Oligomers · Glass transition temperature $\cdot$ Chromium(III) $\cdot$ Oxidovanadium(IV) $\cdot$ Complexes

\section{Introduction}

The complexes of chromium(III) and vanadium(IV) are an important group of catalysts in the polymerization of olefins [1]. Among these catalysts are metallocene and non-metallocene compounds. Chronologically, metallocene catalysts were first designed and used in the polymerization. However, in subsequent years, it was found that metallocene catalysts have several disadvantages, and among others, they are unstable at high temperatures, which are cognizable in the technological process on the industrial scale of polymer production [2].

The characterization of oligomers in terms of morphological and chemical properties is very important to use oligomeric materials in industry [3]. The formation of different conformations of the oligomer chain, as well as the crystallization capacity and generally understood thermal stability of the oligomer, is tested to determine the suitability of oligomers for a given technological process [4]. Among the methods allowing to study the behavior of polymers and oligomers under the influence of heat, thermal analysis and

Dagmara Jacewicz

dagmara.jacewicz@ug.edu.pl

1 Faculty of Chemistry, University of Gdańsk, Wita Stwosza 63, 80-308 Gdańsk, Poland

2 Institute of Chemistry, Jan Kochanowski University, Świętokrzyska 15 G, 25-406 Kielce, Poland differential scanning calorimetry (DSC) occupy an important place [5]. The temperature of glass transition, the melting temperature, the heat capacity, and the crystallization temperature are parameters characterizing the thermal stability of oligomers and polymers.

The chlorine derivative of allyl alcohol, i.e., 2-chloro2-propen-1-ol, is commonly used to obtained oligomers [6-8]. 2-Chloro-2-propen-1-ol forms the oligomers with chains containing from 4 to 15 monomers in the case of using chromium(III) complexes as catalysts. So far, the physicochemical properties of oligomers of poly(2-chloro-allyl alcohol) obtained using chromium(III) complexes: $\left[\mathrm{Cr}(\text { dipic })_{2}\right]$ Hdmbipy. $2.5 \mathrm{H}_{2} \mathrm{O},\left[\mathrm{Cr}(2-\mathrm{pic})_{2}\left(\mathrm{H}_{2} \mathrm{O}\right)_{2}\right] \mathrm{NO}_{3},\left[\mathrm{Cr}(\text { dipic })_{2}\right]$ [Cr(bipy)(dipic) $\left.\mathrm{H}_{2} \mathrm{O}\right] \cdot 2 \mathrm{H}_{2} \mathrm{O},\left[\mathrm{Cr}(\right.$ dipic $\left.)\left(\mathrm{H}_{2} \mathrm{O}\right)_{3}\right] \mathrm{Cl}$, cis$\mathrm{K}\left[\mathrm{Cr}\left(\mathrm{C}_{2} \mathrm{O}_{4}\right)_{2}\left(\mathrm{H}_{2} \mathrm{O}\right)_{2}\right]$, and trans- $\mathrm{K}\left[\mathrm{Cr}\left(\mathrm{C}_{2} \mathrm{O}_{4}\right)_{2}\left(\mathrm{H}_{2} \mathrm{O}\right)_{2}\right] \cdot 3 \mathrm{H}_{2} \mathrm{O}$ (dipic denotes dipicolinate, dmbipy $=4,4$ '-dimethoxy2,2'-bipyridine, 2 -pic $=$ picolinate) have been investigated by the following methods: MALDI-TOF MS, ${ }^{1} \mathrm{H}$ and ${ }^{13} \mathrm{C}$ NMR, IR, and UV-VIS [6-9]. The dipicolinate complexes, i.e., $\left[\mathrm{Cr}(\text { dipic })_{2}\right]\left[\mathrm{Cr}(\right.$ bipy $)($ dipic $\left.) \mathrm{H}_{2} \mathrm{O}\right] \cdot 2 \mathrm{H}_{2} \mathrm{O}$ and [Cr(dipic) $\left.)_{2}\right] \mathrm{Hdmbipy} \cdot 2.5 \mathrm{H}_{2} \mathrm{O}$, have the catalytic activities equal to 2609.86 and $2254.57 \mathrm{~g} \mathrm{mmol}^{-1} \mathrm{~h}^{-1}$, respectively [6]. The picolinate complexes $\left[\mathrm{Cr}(2-\mathrm{pic})_{2}\left(\mathrm{H}_{2} \mathrm{O}\right)_{2}\right] \mathrm{NO}_{3}$ and $\left[\mathrm{Cr}(\right.$ dipic $\left.)\left(\mathrm{H}_{2} \mathrm{O}\right)_{3}\right] \mathrm{Cl}$ exhibit the catalytic activities equal to 1434.33 and $632.5 \mathrm{~g} \mathrm{mmol}^{-1} \mathrm{~h}^{-1}$, respectively [7, 8], whereas the oxalate complexes: cis- $\mathrm{K}\left[\mathrm{Cr}\left(\mathrm{C}_{2} \mathrm{O}_{4}\right)_{2}\left(\mathrm{H}_{2} \mathrm{O}\right)_{2}\right]$ trans $-\mathrm{K}\left[\mathrm{Cr}\left(\mathrm{C}_{2} \mathrm{O}_{4}\right)_{2}\left(\mathrm{H}_{2} \mathrm{O}\right)_{2}\right] \cdot 3 \mathrm{H}_{2} \mathrm{O}$, have very high values of catalytic activities. These values are 2163.25 and 
$3479.15 \mathrm{~g} \mathrm{mmol}^{-1} \mathrm{~h}^{-1}$ for cis- $\mathrm{K}\left[\mathrm{Cr}\left(\mathrm{C}_{2} \mathrm{O}_{4}\right)_{2}\left(\mathrm{OH}_{2}\right)_{2}\right]$ and trans- $\mathrm{K}\left[\mathrm{Cr}\left(\mathrm{C}_{2} \mathrm{O}_{4}\right)_{2}\left(\mathrm{OH}_{2}\right)_{2}\right] \cdot 3 \mathrm{H}_{2} \mathrm{O}$ [9], but attention need to be paid to the fact that there is no literature data on the thermal stability of oligomers obtained using the mentioned catalysts, i.e., poly(2-chloroallyl alcohol). The thermal stability of oligomers such as amorphous styrene oligomers, poly(3hydroxybutyrate), polyethylene terephthalate, oligo[( $\varepsilon$-capro lactone)-co- $\delta$-gluconolactone], poly(2-hexyl-ethylacrylate), and poly(n-butyl acrylate) was investigated recently [10-13]. The temperature drift rate was determined in the vicinity of the glass transition temperature for styrene oligomers [10].

In this reports, we show the results of the studies on the thermal stability of oligomers of 2-chloroallyl alcohol. In particular, we focused on determining the glass transition temperatures of oligomers obtained using catalysts that are polycarboxylate complex compounds of oxovanadium(IV) and chromium(III). These studies have been conducted by two methods: thermal gravimetry (TG) and differential scanning calorimetry (DSC).

\section{Materials and methods}

\section{Syntheses}

The following complexes: $\left[\mathrm{Cr}(\text { dipic })_{2}\right] \mathrm{Hdmbipy} \cdot 2.5 \mathrm{H}_{2} \mathrm{O}$ [6], [Cr(2-pic $\left.)_{2}\left(\mathrm{H}_{2} \mathrm{O}\right)_{2}\right] \mathrm{NO}_{3}$ [7], [Cr(dipic $\left.)_{2}\right][\mathrm{Cr}$ (bipy) (dipic) $\left.\mathrm{H}_{2} \mathrm{O}\right] \cdot 2 \mathrm{H}_{2} \mathrm{O}$ [6], [ $\mathrm{Cr}($ dipic $\left.)\left(\mathrm{H}_{2} \mathrm{O}\right)_{3}\right] \mathrm{Cl}$ [8], cis$\mathrm{K}\left[\mathrm{Cr}\left(\mathrm{C}_{2} \mathrm{O}_{4}\right)_{2}\left(\mathrm{H}_{2} \mathrm{O}\right)_{2}\right][9]$, trans- $\mathrm{K}\left[\mathrm{Cr}\left(\mathrm{C}_{2} \mathrm{O}_{4}\right)_{2}\left(\mathrm{H}_{2} \mathrm{O}\right)_{2}\right] \cdot 3 \mathrm{H}_{2} \mathrm{O}$ [9], [VO(ida) $\left.\left(\mathrm{H}_{2} \mathrm{O}\right)\right] \mathrm{H}_{2} \mathrm{O}$ [14], [VO(ida)(bipy)] $2 \mathrm{H}_{2} \mathrm{O}$ [14], [VO(ida)(phen)] $2 \mathrm{H}_{2} \mathrm{O}$ [15], [VO(oda)(bipy)] $2 \mathrm{H}_{2} \mathrm{O}$ [16], $\left[\mathrm{VO}(\right.$ oda $\left.)\left(\mathrm{H}_{2} \mathrm{O}\right)_{2}\right][16,17]$, and [ $\mathrm{VO}($ oda $)($ phen $\left.)\right] \cdot 1.5 \mathrm{H}_{2} \mathrm{O}$ [16, 17] $($ oda $=$ oxydiacetate, $\mathrm{ida}=$ iminodiacetate, bipy $=2,2$-bipyridine, phen $=1,10$-phenantroline) were synthesized according to the description available in the literature [14-17].

The composition of the all synthesized complexes was determined using an analyzer CARBO ERBA type CHNS-O 1108. Anal. Calcd for $\left.[\mathrm{Cr} \text { (dipic) })_{2}\right][\mathrm{Cr}$ (bipy) (dipic) $\left.\mathrm{H}_{2} \mathrm{O}\right] \cdot 2 \mathrm{H}_{2} \mathrm{O}$ (\%): C, 45.95, H, 2.84, N, 8.65. Found: $\mathrm{C}, 45.88, \mathrm{H}, 2.75, \mathrm{~N}, 8.42$. Anal. Calcd for [Cr(dipic) $)_{2}$ ] Hdmbipy $2.5 \mathrm{H}_{2} \mathrm{O}$ (\%): C, 48.41, H, 3.72, N, 8.69. Found: C, 48.25, H, 3.56, N, 8.57. Anal. Calcd for $\left[\mathrm{Cr}(\operatorname{dipic})\left(\mathrm{H}_{2} \mathrm{O}\right)_{3}\right] \mathrm{Cl}$ (\%): C, 24.52, H, 3.79, N, 4.09. Found: C, 26.64, H, 3.82, N, 4.31. Anal. Calcd for $\left[\mathrm{Cr}(2 \text {-pic })_{2}\left(\mathrm{OH}_{2}\right)_{2}\right] \mathrm{NO}_{3}(\%)$ : C, 36.54, $\mathrm{H}, 3.07, \mathrm{~N}, 10.67$. Found: C, 36.53, H, 3.07, N, 10.55. Anal. Calcd for trans- $\mathrm{K}\left[\mathrm{Cr}\left(\mathrm{C}_{2} \mathrm{O}_{4}\right)_{2}\left(\mathrm{OH}_{2}\right)_{2}\right] \cdot 3 \mathrm{H}_{2} \mathrm{O}(\%)$ : C, 13.66; $\mathrm{H}, 2.85$; and for cis- $\mathrm{K}\left[\mathrm{Cr}\left(\mathrm{C}_{2} \mathrm{O}_{4}\right)_{2}\left(\mathrm{OH}_{2}\right)_{2}\right](\%)$ : C, 15.91; $\mathrm{H}, 1.95$. Found for trans- $\mathrm{K}\left[\mathrm{Cr}\left(\mathrm{C}_{2} \mathrm{O}_{4}\right)_{2}\left(\mathrm{OH}_{2}\right)_{2}\right] \cdot 3 \mathrm{H}_{2} \mathrm{O}: \mathrm{C}$, 13.41; $\mathrm{H}, 2.82$, and for cis- $\mathrm{K}\left[\mathrm{Cr}\left(\mathrm{C}_{2} \mathrm{O}_{4}\right)_{2}\left(\mathrm{OH}_{2}\right)_{2}\right]$ : $\mathrm{C}, 15.19$.; $\mathrm{H}, 1.80$. Anal. Calcd for [VO(oda) $\left.\left(\mathrm{H}_{2} \mathrm{O}\right)_{2}\right](\%): \mathrm{C}, 20.44, \mathrm{H}$, 3.44. Found: $\mathrm{C}, 20.42, \mathrm{H}, 3.45$. Anal. Calcd for [VO(oda) (phen)] $1.5 \mathrm{H}_{2} \mathrm{O}$ (\%): C, 47.27, H, 3.69. Found: C, 47.17, H,
3.64. Anal. Calcd for [VO(oda)(bipy)] $2 \mathrm{H}_{2} \mathrm{O}$ (\%): C, 42.94, $\mathrm{H}, 4$.09. Found: $\mathrm{C}, 42.04, \mathrm{H}, 3.32$. Anal. Calcd for [VO(ida) $\left.\left(\mathrm{H}_{2} \mathrm{O}\right)\right] \cdot \mathrm{H}_{2} \mathrm{O}(\%)$ : C, 20.51, H, 3.84, N, 5.98. Found: C, 21.01, $\mathrm{H}, 3.57, \mathrm{~N}, 6.23$. Anal. Calcd for [VO(ida)(bipy)] $\cdot 2 \mathrm{H}_{2} \mathrm{O}(\%)$ : C, 43.08, H, 4.36, N, 10.77. Found: C, 43.08, H, 4.36, N, 10.74. Anal. Calcd for [VO(ida)(phen)] $2 \mathrm{H}_{2} \mathrm{O}(\%)$ : C, 46.38, H, 4.11, N, 10.14. Found: C, 46.47, H, 4.09, N, 10.17.

\section{The oligomerization process}

The oligomerization was carried out at atmospheric pressure and under nitrogen atmosphere [6, 7]. The complexes of chromium(III) and oxovanadium(IV) were catalysts after activation by MMAO-12. In the first step, $3 \mu \mathrm{mol}$ of the complex was dissolved in toluene $(2 \mathrm{~mL})$. The exception was $\left[\mathrm{Cr}(\text { dipic })_{2}\right]\left[\mathrm{Cr}\right.$ (bipy)(dipic) $\left.\mathrm{H}_{2} \mathrm{O}\right] \cdot 2 \mathrm{H}_{2} \mathrm{O}$, which was used in quantity $1.5 \mu \mathrm{mol}$. The prepared solution containing toluene with the complex was poured into a glass tube with a stopper. The solution was constantly mixed using a magnetic stirrer. Then, MMAO-12 (3 mL) was added to the prepared toluene solution. After that the monomer solution 2-chloro2-propen-1-ol was added dropwise (2-chloro-2-propen-1-ol was purchased from Sigma-Aldrich). All the mixture was stirred for an hour until a gel was obtained. The product was filtered off, dried, and weighed.

\section{TG and DSC tests}

The TG studies were performed using the apparatus Jupiter STA 446 F3 purchased from Netzsch Company. The measurements in the range of low temperatures $-140 \div 0{ }^{\circ} \mathrm{C}$ were performed in helium atmosphere. Thermal analysis in the temperature range of $25 \div 550{ }^{\circ} \mathrm{C}$ was carried out in air atmosphere. The each sample mass was equal $5 \mathrm{~g}$. The heating rate applied to studies equal to $10^{\circ} \mathrm{C} \mathrm{min}^{-1}$.

The differential scanning calorimetry studies were performed using the equipment from Mettler Toledo. The calibration was carried out based on standards of thermal analysis (ind, n-octane). The measurements were conducted in the range from -150 to $500{ }^{\circ} \mathrm{C}$ with the heating rate of $10{ }^{\circ} \mathrm{C} \mathrm{min}{ }^{-1}$ in the inert atmosphere. The sample of the oligomer to the measurements was about $5 \mathrm{mg}$. The liquid nitrogen was used to cooling.

\section{Results and discussion}

The chromium(III) and oxovanadium(IV) complexes (Fig. 1) were used as the catalysts to oligomerization 2-chloro-2-propen-1-ol, and the obtained products were investigated by TG and DSC methods. The TG analysis showed that $75 \%$ of the oligomer is undergoing thermal decomposition up to $90{ }^{\circ} \mathrm{C}$ in the case of $\left[\mathrm{Cr}(\text { dipic })_{2}\right] \mathrm{Hdmbipy} \cdot 2.5 \mathrm{H}_{2} \mathrm{O}$ and up to $100^{\circ} \mathrm{C}$ 
Fig. 1 Chromium(III) and oxovanadium(IV) complexes used as the catalysts<smiles>COc1ccnc(-c2cc(OC)cc[nH+]2)c1</smiles><smiles></smiles>

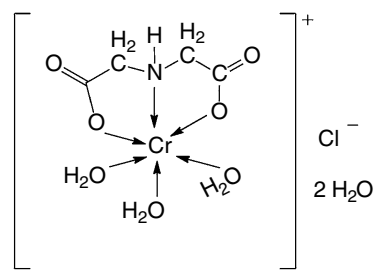<smiles>[3H]C(=O)O[Te](O)(O)(O)(O)OC(=O)CO</smiles>

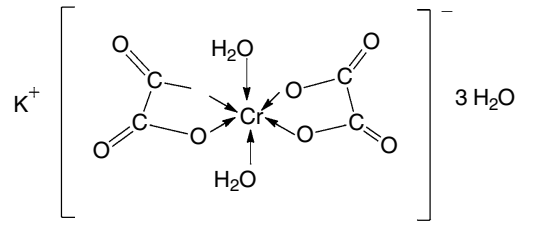
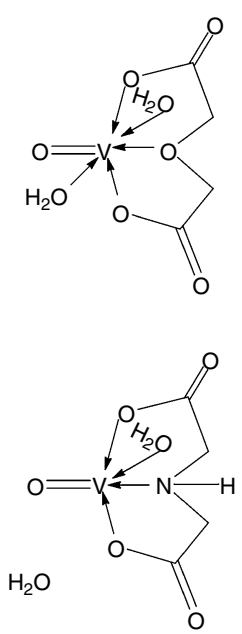

in the case of $\left[\mathrm{Cr}(\text { dipic })_{2}\right]\left[\mathrm{Cr}(\right.$ bipy $)($ dipic $\left.) \mathrm{H}_{2} \mathrm{O}\right] \cdot 2 \mathrm{H}_{2} \mathrm{O}$. $85 \%$ of the oligomer obtained using $\left[\mathrm{Cr}(2-\mathrm{pic})_{2}\left(\mathrm{H}_{2} \mathrm{O}\right)_{2}\right]$ $\mathrm{NO}_{3}$. The oligomer synthesized when applied [Cr(dipic) $\left.\left(\mathrm{H}_{2} \mathrm{O}\right)_{3}\right] \mathrm{Cl}$ as the catalyst is characterized by $35 \%$ mass loss up to $90{ }^{\circ} \mathrm{C}$ and $25 \%$ mass loss in the temperature range $100-620{ }^{\circ} \mathrm{C}$. Analyzing the thermal decomposition of oxalate complexes, it can be concluded that the $80 \%$ oligomer obtained using cis- $\mathrm{K}\left[\mathrm{Cr}\left(\mathrm{C}_{2} \mathrm{O}_{4}\right)_{2}\left(\mathrm{H}_{2} \mathrm{O}\right)_{2}\right]$ as the catalyst undergoes the thermal decomposition up to $120^{\circ} \mathrm{C}$. On the other hand, the product of the oligomerization with trans$\mathrm{K}\left[\mathrm{Cr}\left(\mathrm{C}_{2} \mathrm{O}_{4}\right)_{2}\left(\mathrm{H}_{2} \mathrm{O}\right)_{2}\right] \cdot 3 \mathrm{H}_{2} \mathrm{O}$ decomposes $85 \%$ up to $100{ }^{\circ} \mathrm{C}$. For the complexes of oxovanadium(IV), thermal decomposition occurs in clearly marked stages. The first stage of

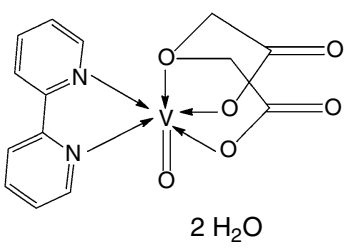

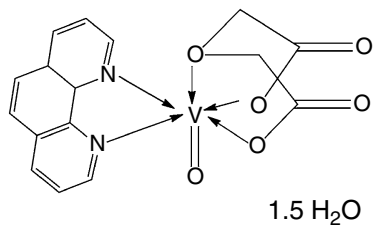

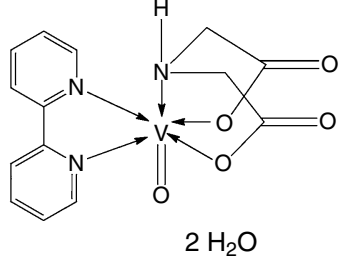<smiles>O=C1CN(S(=O)(=O)N2CC=CC3C=Cc4ccn2c43)CC(=O)O1</smiles>

the thermal decomposition of the oligomer obtained with [ VO (oda) $\left(\mathrm{H}_{2} \mathrm{O}\right)_{2}$ ] includes $10.2 \%$ mass loss up to $200{ }^{\circ} \mathrm{C}$. The second stage continues up to $360{ }^{\circ} \mathrm{C}$ and includes $45 \%$ mass loss. In the case of $[\mathrm{VO}$ (oda)(bipy) $] \cdot 2 \mathrm{H}_{2} \mathrm{O}$, two steps of the mass loss about $20 \%$ are observed up to $340{ }^{\circ} \mathrm{C}$ and $480-500{ }^{\circ} \mathrm{C}$. The oligomers synthesized using [VO(oda) (phen)] $1.5 \mathrm{H}_{2} \mathrm{O},\left[\mathrm{VO}(\mathrm{ida})\left(\mathrm{H}_{2} \mathrm{O}\right)\right] \mathrm{H}_{2} \mathrm{O}$, and [VO(ida) (bipy)] $\cdot 2 \mathrm{H}_{2} \mathrm{O}$ decompose in three steps: $5 \%$ (up to $90{ }^{\circ} \mathrm{C}$ ), $40 \%\left(300-340{ }^{\circ} \mathrm{C}\right), 10 \%\left(480-520{ }^{\circ} \mathrm{C}\right) ; 6 \%\left(100{ }^{\circ} \mathrm{C}\right), 45 \%$ $\left(220-420{ }^{\circ} \mathrm{C}\right), 10 \%\left(460-560{ }^{\circ} \mathrm{C}\right.$ ); and $10 \%$ (up to $280{ }^{\circ} \mathrm{C}$ ), $20 \%$ (up to $360{ }^{\circ} \mathrm{C}$ ), $12 \%\left(380-520{ }^{\circ} \mathrm{C}\right.$ ), respectively. In the case of oligomer obtained using [VO(ida)(phen)] $2 \mathrm{H}_{2} \mathrm{O}$, thermal decomposition occurs in two stages: first at $100{ }^{\circ} \mathrm{C}$ 
(5\% mass loss) and the second in the temperature range $275-500{ }^{\circ} \mathrm{C}$ (30\% mass loss). The oligomers of 2-chloro2-propen-1-ol decompose with release $\mathrm{CO}_{2}, \mathrm{H}_{2} \mathrm{O}, \mathrm{HCl}$, and $\mathrm{CO}$. The oligomers of poly(2-chloroallylalcohol) thermally decompose in such a way that first water is released, then $\mathrm{CO}$ and $\mathrm{HCl}$, and finally in the largest amounts of $\mathrm{CO}_{2}$. The fact that some oligomers undergo thermal decomposition in two or three stages may be due to different cross-linking of the chains. The oligomers obtained using the following catalysts decompose the longest as a function of temperature: $[\mathrm{VO}($ oda $)($ phen $)] \cdot 1.5 \mathrm{H}_{2} \mathrm{O},\left[\mathrm{VO}(\mathrm{ida})\left(\mathrm{H}_{2} \mathrm{O}\right)\right] \mathrm{H}_{2} \mathrm{O}$ and $\left[\mathrm{Cr}\right.$ (dipic) $\left.\left(\mathrm{H}_{2} \mathrm{O}\right)_{3}\right] \mathrm{Cl}$. These oligomers thermally decompose to temperatures over $500{ }^{\circ} \mathrm{C}$. The oligomer obtained with using [ VO(oda)(bipy)] $2 \mathrm{H}_{2} \mathrm{O}$ is the most thermally stable. It only decomposes above $340{ }^{\circ} \mathrm{C}$. The thermal behavior of oligomers is very similar for almost every complex compounds used as catalysts. This may indicate that the oligomers obtained have a similar structure and crosslinking in all cases tested.

The glass transition temperature values for the oligomers obtained using the polycarboxylate complexes of chromium(III) and oxovanadium(IV) were determined by DSC method. An example graph obtained by the DSC method for the oligomer obtained using complex [ $\mathrm{Cr}(2-$ pic) $\left.)_{2}\left(\mathrm{H}_{2} \mathrm{O}\right)_{2}\right]_{N_{3}}$ as the catalyst is shown in Fig. 2, and the glass transition temperature values for all oligomers are shown in Table 1. Figure 2 shows that the glass transition consists of the following stages: at $-89.5^{\circ} \mathrm{C}$ is onset, mid-stage occurs at $-87.3{ }^{\circ} \mathrm{C}$, deflection is observed at $-87.1^{\circ} \mathrm{C}$, and the end of the process occurs at $-83.9^{\circ} \mathrm{C}$.
Table 1 Glass transition temperature values for oligomers obtained using these complexes as catalysts

\begin{tabular}{ll}
\hline Compound & $T_{\mathrm{g}} /{ }^{\circ} \mathrm{C}$ \\
\hline$\left[\mathrm{Cr}(2-\text { pic })_{2}\left(\mathrm{H}_{2} \mathrm{O}\right)_{2}\right] \mathrm{NO}_{3}$ & -87.3 \\
{$\left[\mathrm{Cr}(\text { dipic })_{2}\right]\left[\mathrm{Cr}(\right.$ bipy $)($ dipic $\left.) \mathrm{H}_{2} \mathrm{O}\right] \cdot 2 \mathrm{H}_{2} \mathrm{O}$} & -86.2 \\
cis- $\mathrm{K}\left[\mathrm{Cr}\left(\mathrm{C}_{2} \mathrm{O}_{4}\right)_{2}\left(\mathrm{H}_{2} \mathrm{O}\right)_{2}\right]$ & -87.5 \\
trans $-\mathrm{K}\left[\mathrm{Cr}\left(\mathrm{C}_{2} \mathrm{O}_{4}\right)_{2}\left(\mathrm{H}_{2} \mathrm{O}\right)_{2}\right] \cdot 3 \mathrm{H}_{2} \mathrm{O}$ & -89.0 \\
$\mathrm{VO}($ oda $)\left(\mathrm{H}_{2} \mathrm{O}\right)_{2}$ & -90.5 \\
{$[\mathrm{VO}($ oda $)($ bipy $)] \cdot 2 \mathrm{H}_{2} \mathrm{O}$} & -85.9 \\
{$[\mathrm{VO}($ oda $)($ phen $)] \cdot 1.5 \mathrm{H}_{2} \mathrm{O}$} & $-85.4 ;-10.3$ \\
{$[\mathrm{VO}($ ida $)($ bipy $)] \cdot 2 \mathrm{H}_{2} \mathrm{O}$} & $-84.5 ;-15.9$ \\
{$[\mathrm{VO}($ ida $)($ phen $)] \cdot 2 \mathrm{H}_{2} \mathrm{O}$} & $-85.4 ;-14.6$ \\
{$\left[\mathrm{VO}(\right.$ ida $\left.)\left(\mathrm{H}_{2} \mathrm{O}\right)\right] \cdot \mathrm{H}_{2} \mathrm{O}$} & -87.0 \\
{$\left[\mathrm{Cr}(\right.$ dipic $\left.)\left(\mathrm{H}_{2} \mathrm{O}\right)_{3}\right] \mathrm{Cl}$} & $-86.8 ;-16.7$ \\
\hline
\end{tabular}

The glass transition temperature for polyvinyl chloride (PVC) ranges from 77 to $80{ }^{\circ} \mathrm{C}$ depending on the molecular mass [18]. However, for amorphous styrene oligomers, glass transition temperatures are in the range of $-53{ }^{\circ} \mathrm{C}$ to $-3{ }^{\circ} \mathrm{C}[10]$. It is also worth noting that amorphous styrene oligomers undergo thermal decomposition in two stages only [10].

The tested oligomers in this report are of a kind of PVC derivative; however, the glass transition temperature values are diametrically different. It is probably because PVC is a polymer sample, but the samples studied and described in this report are short oligomer chains [19, 20].
Fig. 2 TG, DTG, and DSC curves of the sample of the oligomer obtained using $[\mathrm{Cr}(2-$ pic $\left.)_{2}\left(\mathrm{H}_{2} \mathrm{O}\right)_{2}\right]_{N_{3}}$

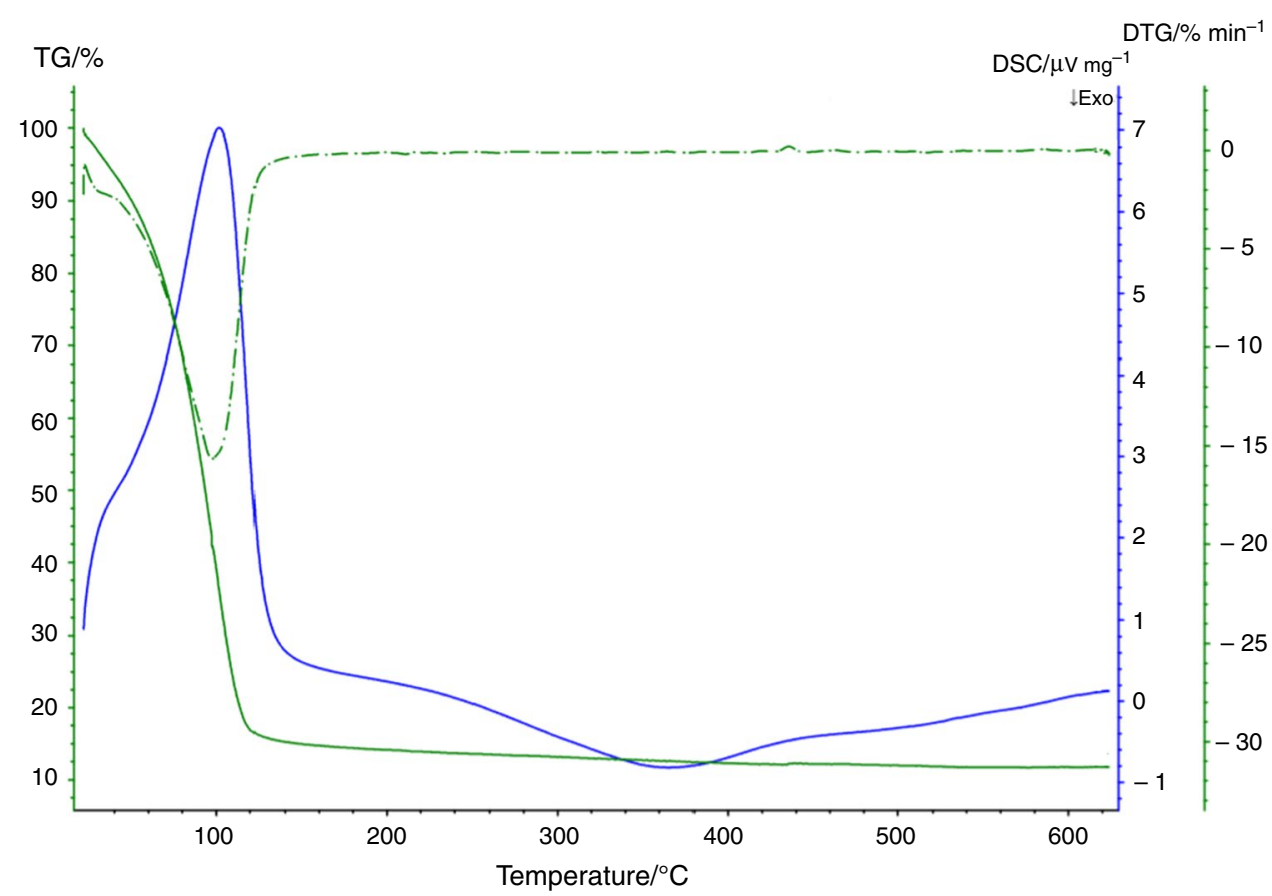




\section{Conclusions}

Twelve oligomer samples have been tested for thermal stability and to determine their glass transition temperatures. One compound among the tested catalysts, i.e., [VO(oda) (bipy) $] \cdot 2 \mathrm{H}_{2} \mathrm{O}$, produces the oligomer with the highest thermal stability up to $340{ }^{\circ} \mathrm{C}$. The glass transition temperature values were determined for the oligomers synthesized with using the dipicolinate, oxalate and 2-picolinate complexes of chromium(III) and for oxydiacetate and iminodiacetate complexes of oxovanadium(IV) as the catalysts. The determined glass transition temperature values have very low values in the range from -90.5 to $10.3{ }^{\circ} \mathrm{C}$. This range is due to different tactics and crosslinking of oligomer chains.

Acknowledgements This work was supported by National Science Centre, Poland [grant number 2015/19/N/ST5/00276].

Open Access This article is licensed under a Creative Commons Attribution 4.0 International License, which permits use, sharing, adaptation, distribution and reproduction in any medium or format, as long as you give appropriate credit to the original author(s) and the source, provide a link to the Creative Commons licence, and indicate if changes were made. The images or other third party material in this article are included in the article's Creative Commons licence, unless indicated otherwise in a credit line to the material. If material is not included in the article's Creative Commons licence and your intended use is not permitted by statutory regulation or exceeds the permitted use, you will need to obtain permission directly from the copyright holder. To view a copy of this licence, visit http://creativecommons.org/licenses/by/4.0/.

\section{References}

1. Gibson VC, Spitzmesser SK. Advances in non-metallocene olefin polymerization catalysis. Chem Rev. 2003;103:283-316.

2. Britovsek GJ, Gibson VC, Wass DF. The search for new-generation olefin polymerization catalysts: life beyond metallocenes. Angew Chem Int Ed. 1999;38:428-47.

3. Tang F, Bao P, Su Z. Analysis of nanodomain composition in high-impact polypropylene by atomic force microscopy-infrared. Anal Chem. 2016;88:4926-30.

4. Adams A. Analysis of solid technical polymers by compact NMR. TRAC Trend Anal Chem. 2016;83:107-19.

5. Schindler A, Doedt M, Gezgin Ş, Menzel J, Schmölzer S. Identification of polymers by means of DSC, TG, STA and computer-assisted database search. J Therm Anal Calorim. 2017;129:833-42.

6. Drzeżdżon J, Sikorski A, Chmurzyński L, Jacewicz D. New type of highly active chromium(III) catalysts containing both organic cations and anions designed for polymerization of beta-olefin derivatives. Sci Rep. 2018;8:2315.

7. Drzeżdżon J, Sikorski A, Chmurzyński L, Jacewicz D. Oligomerization of 2-chloroallyl alcohol by 2-pyridinecarboxylate complex of chromium(III)-new highly active and selective catalyst. Sci Rep. 2018;8:8632.
8. Drzeżdżon J, Zych D, Malinowski J, Sikorski A, Chmurzyński L, Jacewicz D. Formation of 2-chloroallyl alcohol oligomers using a new crystalline dipicolinate complex of $\mathrm{Cr}(\mathrm{III})$ as a catalyst. J Catal. 2019;375:287-93.

9. Drzeżdżon J, Chmurzyński L, Jacewicz D. Geometric isomerism effect on catalytic activities of bis(oxalato) diaquochromates(III) for 2-chloroallyl alcohol oligomerization. J Chem Sci. 2018;130:116.

10. Fujimura J, Nishiyama E, Tsukushi I, Shibata M. Enthalpy relaxation of low molecular weight amorphous styrene oligomers measured with an adiabatic calorimeter. J Therm Anal Calorim. 2019;135(5):2813-7.

11. Dias DS, Crespi MS, Ribeiro CA, Kobelnik M. Evaluation of the thermal decomposition of blends prepared with poly (3-hydroxybutyrate)(PHB) and recyclable ethylene poly-terephthalate (RPET). J Therm Anal Calorim. 2020. https://doi.org/10.1007/ s10973-020-09885-4.

12. Boudraa K, Bouchaour T, Maschke U. Thermal analysis of interpenetrating polymer networks through molecular dynamics simulations: a comparison with experiments. J Therm Anal Calorim. 2020;140:1845-57.

13. Todea A, Aparaschivei D, Bîtcan I, Ledeți IV, Bandur G, Péter F, Lajos N, Sándor K, Biró E. Thermal behavior of oligo[( $\varepsilon$ caprolactone)-co- $\delta$-gluconolactone] enzymatically synthesized in reaction conditions optimized by experimental design. J Therm Anal Calorim. 2020. https://doi.org/10.1007/s10973-020-09557 -3 .

14. Pranczk J, Wyrzykowski D, Jacewicz D, Sikorski A, Tesmar A, Chmurzyński L. Structural, physico-chemical and antioxidant characteristics of 2,2'-bipyridyl(iminodiacetato) oxidovanadium(IV) dehydrate. Polyhedron. 2015;100:74-81.

15. Pranczk J, Jacewicz D, Wyrzykowski D, Wojtczak A, Tesmar A, Chmurzyński L. Crystal structure, antioxidant properties and characteristics in aqueous solutions of the oxidovanadium(IV) complex [VO(IDA)phen] $2 \mathrm{H}_{2} \mathrm{O}$. Eur J Inorg Chem. 2015;2015:3343-9.

16. Siddiqi ZA, Sharma PK, Shahid M, Khalid M, Kumar S. Synthesis, spectral characterizations and biological studies of transition metal mixed ligand complexes: $\mathrm{X}$-ray crystal structures of $\left[\mathrm{Cu}(\right.$ oda $\left.)(\mathrm{Bipy})\left(\mathrm{H}_{2} \mathrm{O}\right)\right] \cdot 4 \mathrm{H}_{2} \mathrm{O}$ and $[\mathrm{VO}($ oda $)(\mathrm{Bipy})] \cdot 2 \mathrm{H}_{2} \mathrm{O}$. J Mol Struct. 2011;994:295-301.

17. Pranczk J, Tesmar A, Wyrzykowski D, Inkielewicz-Stępniak I, Jacewicz D, Chmurzyński L. Influence of primary ligands (ODA, TDA) on physicochemical and biological properties of oxidovanadium (IV) complexes with bipy and phen as auxiliary ligands. Biol Trace Elem Res. 2016;174:251-8.

18. Pezzin G, Zilio-Grandi F, Sanmartin P. The dependence of the glass transition temperature on molecular weight for polyvinylchloride. Eur Polym J. 1970;6:1053-61.

19. Burfield DR, Doi Y. Differential scanning calorimetry characterization of polypropylene. Dependence of $T_{g}$ on polymer tacticity and molecular weight. Macromolecules. 1983;16:702-4.

20. Takasu A, Niwa T, Itou H, Inai Y, Hirabayashi T. Chemical modification of hydroxyl groups of poly (vinyl alcohol) by a glycosidation reaction. Macromol Rapid Commun. 2000;21:764-9.

Publisher's Note Springer Nature remains neutral with regard to jurisdictional claims in published maps and institutional affiliations. 